\title{
Refusal-To-Recognize Charges Under Section 8(a) (5) of the NLRA: Card Checks and Employee Free Choice
}

The National Labor Relations Act provides two methods by which a union can obtain recognition as the exclusive bargaining representative of a previously unorganized group of employees. The first, based on section 9 of the act, ${ }^{1}$ is through the familiar procedures of election and certification. The second is based on section $8(a)(5),{ }^{2}$ which states only that "it shall be an unfair labor practice for an employer ... to refuse to bargain collectively with the representatives of his employees," but has been interpreted to mean that "an employer is under a duty to bargain as soon as the union representative presents convincing evidence of majority support." 3 Such evidence of support may consist of, among other things, employee participation in a union-called strike or strike vote, ${ }^{4}$ or employees' signatures on cards authorizing the union in question to act as their exclusive bargaining representative. ${ }^{5}$

Section $8(a)(5)$ refusal-to-recognize charges ${ }^{\ell}$ are a much less frequently used method of obtaining recognition than are the election and certi-

161 Stat. 143 (1947), 29 U.S.C. $\$ 159$ (1964). In a certification proceeding the union first files a petition showing that at least $30 \%$ of the employees in the bargaining unit in question have indicated an interest in an election or in union representation. Then, if certain standards as to the execution of the petition and the appropriateness of the bargaining unit have been met, the Board will hold a secret ballot election in which the employees in the unit may vote. If the union wins a majority of the votes cast in the election, the Board will certify it as the exclusive bargaining representative for the unit. See generally, 1964 CCH GuidebooK to LABOR Relations $\S \S 400-12$; Silverberc, How To Take a Gase before the National labor Relations Board 58-156 (1959).

261 Stat. 141 (1947), 29 U.S.C. § 158(a)(5) (1964).

3 NLRB v. Dahlstrom Metallic Door Co., 112 F.2d 756, 757 (2d Cir. 1940); accord, Colson Corp. v. NLRB, 347 F.2d 128 (8th Cir. 1965); NLRB v. "Philamon Labs., 298 F.2d 176 (2d Cir.), cert. denied, 370 U.S. 919 (1962); NLRB v. Sunrise Lumber \& Trim Corp., 241 F.2d 620 (2d Cir.), cert. denied, 355 U.S. 818 (1957); NLRB v. Piqua Munising Wood Prods. Co., 100 F.2d 552 (6th Cir. 1940).

Voluntary recognition by the employer is, of course, a third important method by which unions secure exclusive bargaining representative status.

4 See, e.g., Denver Auto. Dealers Ass'n, 10 N.L.R.B. 1173, 3 L.R.R.M. 514 (1939); C. A. Lund Co., 6 N.L.R.B. 423, 2 L.R.R.M. 170 (1938), rev'd on other grounds, 103 F.2d 815 (8th Cir. 1939); Century Mills, Inc., 5 N.L.R.B. 807, 2 L.R.R.M. 61 (1938); Rabhor Co., 1 N.L.R.B. 470 (1986).

5 See notes 16-19 infra and accompanying text.

6 In Board and court decisions, charges of this sort are referred to as "refusal-to-bargain" 
fication procedures of section 9. For example, from July 1, 1961, to June 30, 1965, the Board conducted 29,728 elections, ${ }^{7}$ while during the same period it ordered employers to recognize and bargain with unions on the basis of section $8(a)(5)$ charges in only 733 cases. $^{8}$ Since 1961, however, the NLRB has handed down three major decisions that have significantly expanded the employer's obligation to bargain on the basis of nonelective showings of support. ${ }^{9}$ As a result, use of the section $8(a)(5)$ method of obtaining recognition has dramatically increased. Fifty per cent more refusal-to-recognize bargaining orders were issued in the Board's fiscal year 1965 than were issued three years before; in fiscal 1965 alone, the increase was $36 \% .^{10}$ This is much greater than the rate of increase in the number of elections conducted per year. ${ }^{11}$

The recent trend toward greater reliance on refusal-to-recognize charges and correspondingly less reliance on elections in settling issues of union recognition has been condemned by commentators and legislators. ${ }^{12}$ In Congress, two Senators have introduced bills designed to undo a recent Board innovation in this area, ${ }^{13}$ and arguments on these

charges. However, since that term is also used to refer to controversies dealing with matters such as the scope of the bargaining and the data to be furnished for bargaining, this comment employs the more restrictive term "refusal-to-recognize" charges.

7 The Board conducted 7,355 elections in fiscal year 1962, 7,240 in fiscal year 1963, 7,309 in fiscal year 1964, and 7,824 in fiscal year 1965. 29 NLRB ANN. REP. 19 (1964); 28 NLRB ANN. REP. 16 (1963); 27 NLRB ANN. REP. 16 (1962); Letter From Edward Goodstein, Assistant Director of the Division of Administration of the NLRB, to The University of Chicago Law Review, Nov. 1, 1965, on file in the Review office. The Board's fiscal year extends from July 1 of the preceding calendar year to June 30 of the calendar year cited.

8 The Board issued 157 such orders in fiscal year 1962, 165 in fiscal 1963, 175 in fiscal 1964, and 236 in fiscal 1965. Letter From Edward Goodstein, supra note 7, Oct. 7, 1965.

9 Bernel Foam Prods. Co., 146 N.L.R.B. 1277, 59 L.R.R.M. 1039 (1964); Cumberland Shoe Corp., 144 N.L.R.B. 1286, 54 L.R.R.M. 1233 (1963); Fred Snow, 134 N.L.R.B. 709, 49 L.R.R.M. 1228 (1961), enforced, 308 F.2d 687 (9th Cir. 1962). Although each of these cases was decided shortly after a new Democratic administration took office, there does not appear to be any clear correlation between the political composition of the Board and its policies in the refusal-to-recognize area. Cumberland was heard by a three member panel consisting of two Eisenhower appointees and one Kennedy appointee; the decision was unanimous. Snow was heard by the full Board, which then consisted of three Eisenhower appointees and two Kennedy appointees; two of the Eisenhower appointees and both of the Kennedy appointees joined in the decision. Bernel Foam was also heard by the full Board, which by that time consisted of three Kennedy appointees and two Eisenhower appointees; two of the Kennedy appointees and one Eisenhower appointee joined in the majority opinion.

10 See note 8 supra.

11 The number of elections conducted per year increased by only 6\% from fiscal 1962 to fiscal 1965. See note 7 supra.

12 See, e.g., Lewis, The Use and Abuse of Authorization Cards in Determining Union Majority, 16 LAB. L.J. 434 (1965); Sandler, Another Worry for Employers, U.S. News \&: World Rep., March 15, 1965, p. 86; Shuman, Requiring a Union To Demonstrate Its Majority Status by Means of an Election Becomes Riskier, I6 LAB. L.J. 426 (1965).

13 S. 2133, 89th Cong., Ist Sess. (1965) (introduced by Senator Jacob Javits of New York); S. 2226, 89th Cong., 1st Sess. (1965) (introduced by Senator Paul Fannin of Arizona). 
measures were heard in connection with the attempt to repeal section 14(b) of the NLRA. ${ }^{14}$ The controversy also raises troublesome questions of fundamental labor law policy. For thirty years parties have argued whether the primary purpose of the NLRA is to encourage the spread of unionism or to protect employee free choice. ${ }^{15}$ The Board's earlier, more restrictive policies in the refusal-to-recognize area appeared to emphasize the protecting of employee free choice; its current policies, by contrast, seem to emphasize the promoting of the spread of unionism. The shifting contours of the Board's policy and the controversy it has generated make it timely to reexamine refusalto-recognize law.

\section{The Gard Check Process and Its Relmability}

In seeking recognition via section $8(a)(5)$ unions most frequently rely upon obtaining signatures on authorization cards from a majority of the employees in the bargaining unit in question. Authorization cards, according to Board and court decisions, may take the form of regular union membership cards, ${ }^{16}$ explicit designations of the union as the signer's exclusive bargaining representative, ${ }^{17}$ applications for union membership, ${ }^{18}$ or authorizations for the checkoff of union dues. ${ }^{19}$ Once a union has obtained the requisite number of signatures, it may present the cards either to the employer or to a neutral third party,

14 See, e.g., Hearings on S. 256 Before the Subcommittee on Labor of the Senate Committee on Labor and Public Welfare, 89th Cong., Ist Sess. 19 (1965).

15 Among the articles that discuss various aspects of this pervasive theme are Cox, Some Aspects of the Labor Management Relations Act, 1947 (pts. 1-2), 61 HARv. L. REv. 1, 274 (1947-1948); Meltzer, Organizational Picketing and the NLRB: Five on a Seesaw, $30 \mathrm{U}$. CHI. L. REv. 78 (1962).

16 See, e.g., Joy Silk Mills, Inc. v. NLRB, 185 F.2d 732 (D.C. Cir. 1950), cert. denied, 341 U.S. 914 (1951); NLRB v. Federbush, 121 F.2d 954 (2d Cir. 1941); NLRB v. Dahlstrom Metallic Door Co., 112 F.2d 756 (2d Cir. 1940). The fact that the signers of such cards may never have become actual members or paid union dues or initiation fees is of no consequence. NLRB v. Bradford Dyeing Ass'n, 310 U.S. 318 (1940); NLRB v. Chicago Apparatus Co., 116 F.2d 753 (7th Cir. 1940).

17 See, e.g., NLRB v. Stow Mfg. Co., 217 F.2d 900 (2d Cir.), cert. denied, 348 U.S. 964 (1954); NLRB v. Geigy Co., 211 F.2d 553 (9th Cir.), cert. denied, 348 U.S. 821 (1954); NLRB v. Howell Chevrolet Co., 204 F.2d 79 (9th Cir.), aff'd, 346 U.S. 482 (1953); NLRB v. W. T. Grant Co., 199 F.2d 711 (9th Cir. 1952), cert. denied, 344 U.S. 928 (1953). A jointly signed petition is also acceptable. NLRB v. Fargo Foundry Co., 141 F.2d 462 (8th Gir. 1944).

18 See, e.g., NLRB v. Bradford Dyeing Ass'n, 310 U.S. 318 (1940); NLRB v. Consolidated Mach. Tool Corp., 163 F.2d 376 (2d Cir.), cert. denied, 332 U.S. 824 (1947); NLRB v. Somerset Shoe Co., 111 F.2d 681 (lst Cir. 1940); NLRB v. Louisville Ref. Co., 102 F.2d 678 (6th Cir.), cert. denied, 308 U.S. 568 (1939).

10 See Lebanon Steel Foundry v. NLRB, 130 F.2d 404 (D.C. Cir.), cert. denied, 317 U.S. 659 (1942). 
such as a clergyman or a judge, for a check against payroll records. ${ }^{20}$ If the employer then refuses to recognize the union, the latter may bring a refusal-to-recognize charge before the NLRB, and if the Board finds that the union in fact presented "convincing evidence of majority support," it will order the employer to recognize and bargain upon demand. ${ }^{21}$

Compared to NLRB election and certification procedures, the card check process has two significant shortcomings. First, the lack of secrecy in card campaigns subjects employees to forms of subtle coercion against which secret ballot election procedures offer important protection. In a card campaign an employee may reluctantly sign a card to do a favor for a friend, to avoid an argument, or to buy peace from the harassment of a union organizer. ${ }^{22}$ The informality of the card check process contributes to this problem by encouraging signing without reflection. Second, whereas in a Board election the employer generally has an opportunity to exercise the rights of "free speech" guaranteed to him by section 8 (c) of the NLRA, ${ }^{23}$ in a card campaign he may not realize that a union is soliciting support among his employees until he is presented with a demand for immediate recognition. By that time, of course, it is too late for him to present his side of the argument. Consequently, employees who sign authorization cards may know very little about the possible disadvantages of unionism, such as initiation fees and special assessments, fines for the violation of union rules, and obligations to walk the picket line in any strike involving the union.

Available statistics support the hypothesis that card checks are not as reliable a method of determining union support as are Board elections. According to figures contained in a 1962 speech by NLRB Chairman Frank McGulloch, ${ }^{24}$ unions win $52 \%$ of elections held after authoriza-

20 See, e.g., NLRB v. George Groh \& Sons, 329 F.2d 265 (10th Cir. 1964); Snow v. NLRB, 308 F.2d 687 (9th Cir. 1962).

21 The point at which the existence or nonexistence of the union's majority is determined may be either the date on which the employer received the union's letter requesting recognition, Allegheny Pepsi-Cola Bottling Co. v. NLRB, 312 F.2d 529 (3rd Cir. 1962), or the date on which the employer refused recognition, Burton-Dixie Corp., 103 N.L.R.B. 880, 31 L.R.R.M. 1589 (1953), enforced, 210 F.2d 199 (10th Cir. 1954). That unfair labor practices by the employer may subsequently have destroyed the union's majority is of no consequence. Franks Bros. Co. v. NLRB, 321 U.S. 702 (1944); NLRB v. P. Lorillard Co., 314 U.S. 512 (1942); NLRB v. Bradford Dyeing Ass'n, 310 U.S. 318 (1940).

22 See, e.g., Peterson Bros., Inc., 144 N.L.R.B. 679, 54 L.R.R.M. 1113 (1963), enforced in part and rev'd in part, 342 F.2d 221 (5th Cir. 1965); Philamon Labs., Inc., 131 N.L.R.B. 80, 47 L.R.R.M. 1606 (1961), enforced, 298 F.2d 176 (2d Cir.), cert. denied, 370 U.S. 919 (1962).

2361 Stat. 142 (1947), 29 U.S.C. \& 158(c) (1964).

24 Section of Labor Relations Law, American Bar Association, 1962 Proceedings 17. Chairman McCulloch's figures were based on a study made by the Board's Atlanta office, which handles cases arising in Georgia, eastern Tennessee, and northern Alabama. It should 
tion cards have been obtained from $50 \%$ to $70 \%$ of the employees in the bargaining unit, and $74 \%$ of elections held after cards have been obtained from more than $70 \%$ of such employees. If the results obtained in the elections subsequent to the card check proceedings are assumed to be the best available index to the actual levels of support enjoyed by the unions concerned, these data suggest that results obtained in card check determinations tend to give an overly optimistic impression of union strength. ${ }^{25}$ Although it may be argued that the results of a single study should not be regarded as conclusive, Chairman McGulloch's data are the only statistics on the subject, and their source is sufficiently responsible to justify reliance on them until additional information becomes available.

On several occasions the Board itself has expressed awareness of the shortcomings of card check determinations. Under section 9 of the original Wagner $\mathrm{Act}^{26}$ it was empowered to certify unions with or without an election, and for several years it followed the practice of granting certifications on the basis of authorization card showings. ${ }^{27}$ In 1939, however, it abandoned this practice on the ground that secret ballot procedures were more appropriate to the purposes of the act.28 Similarly, in the Midwest Piping case of 1945, where two rival unions were claiming a card majority, the Board stated that "it is well known that membership cards obtained during the heat of rival organizing campaigns ... do not necessarily reflect the ultimate choice of a bargaining representative." 29 Expressions of doubt as to the reliability of the card check process have also come from such supporters of the Board's current policies as Secretary of Labor Willard Wirtz ${ }^{30}$ and even the AFL-CIO. ${ }^{31}$

be noted that the Atlanta study was made in 1960, three years before the Board's decision in Cumberland Shoe Corp., 144 N.L.R.B. 1268, 54 L.R.R.M. 1283 (1963), discussed in text accompanying notes 40-42 infra. Since Cumberland lowered the standards used to determine the validity of authorization cards, it seems probable that a similar study undertaken today would show even less correlation between card check and election results.

25 Chairman McCulloch, however, cited these data as evidence of "the close correlation between the union showing of interest and the election result." SEction of LABOR RELAnows LAw, op. cit. supra note 24, at 17-18.

2649 Stat. 453 (1935). The provision in question was amended by Congress in 1947. 61 Stat. 143 (1947).

27 Memorandum from Secretary of Labor Willard Wirtz to Senator Jacob Javits, in Hearings on S. 256 Before the Subcommittee on Labor of the Senate Committee on Labor and Public Welfare, 89th Cong., 1st Sess. 19, 20 (1965).

28 Cudahy Packing Co., 13 N.L.R.B. 526, 4 L.R.R.M. 321 (1939).

29 Midwest Piping \& Supply Co., 63 N.L.R.B. 1060, 1070 n.13, 17 L.R.R.M. 40 (1945).

30 "The procedure for determining a majority wish for union representation by means of cards is uniformly recognized as less satisfactory than a secret vote in an election ...." Wirtz Memorandum in Hearings on S. 256 Before the Subcommittee on Labor of the Senate Committee on Labor and Public Welfare, 89th Cong., 1st Sess. 19 (1965).

31 "NLRB pledge cards are at best a signifying of intention at a given moment. Some- 
Indications that the card check process is not as reliable a method of determining union support as are secret ballots conducted under section 9 are perhaps of little importance if the primary purpose of the NLRA is that of encouraging the spread of unionism. In another context, however, the Supreme Court has stated that "there can be no greater abridgment of section 7 of the Act, assuring employees the right 'to bargain collectively through representatives of their own choosing' or 'to refrain from' such activity," than to grant "exclusive bargaining status to an agency selected by a minority of employees, thereby impressing that agency on the nonconsenting majority." 32 If, as the Supreme Court's statement would seem to indicate, an important purpose of the NLRA is that of protecting employee free choice, the unreliability of the card check process must be regarded as a serious shortcoming.

\section{The Validity of the Authorization Card: The Cumberland Shoe Corp. Decision}

The initial point of inquiry in every refusal-to-recognize case is whether a majority of the employees in the bargaining unit actually did authorize the union to act as their exclusive bargaining representative. When an issue of the validity of specific authorization cards reaches a trial examiner hearing, the customary procedure is for the trial examiner to call in the alleged signers of the cards to have them identify their signatures: ${ }^{33}$ If an employee testifies that his signature was forged ${ }^{34}$ or that he signed as a result of union threats, ${ }^{35}$ his card will not be counted. It is generally said, however, that "an employee's thoughts (or afterthoughts) as to why he signed a union card, and what he thought the card meant, cannot negative the overt act of having signed ...."."36

The NLRA sets out no criteria for determining the validity of au-

times they are signed 'to get the union off my back.' .. . Whatever the reason, there is no guarantee of anything in a signed NLRB pledge card except that it will count toward an NLRB election." AFL-CIO 1961 GUIDEBook FOR UNION ORGanizers, as quoted in Sandler, supra note 12, at 86. (Italics in original.)

32 International Ladies' Garment Workers v. NLRB, 366 U.S. 731, 737 (1961).

33 Lewis, supra note 12 , at 436.

34 See, e.g., IMCO Container Co., 148 N.L.R.B. 312, 56 L.R.R.M. 1497 (1964).

35 See, e.g., I. Posner, Inc., 133 N.L.R.B. I573, 49 L.R.R.M. 1062 (1961).

36 Colson Corp. v. NLRB, 347 F.2d 128, 135 (8th Cir.), cert. denied, 34 U.S.L. WEEK 3160 (U.S. Nov. 9, 1965) (No. 468); NLRB v. Winn-Dixie Stores, Inc., 341 F.2d 750, 755 (6th Cir. 1965); Joy Silk Mills, Inc. v. NLRB, 185 F.2d 732, 743 (D.C. Cir. 1950), cert. denied, 341 U.S. 914 (1951). 
thorization cards; in fact, it fails to mention authorization cards altogether. As one court of appeals stated, "the Wagner Act requires no specific form of authority to bargain collectively. . . . Not form, but intent, is the essential thing." 37 It would appear, however, that even in the absence of statutory requirements as to form, union misrepresentation as to a card's purpose should invalidate it. This appeared to be the Board's reasoning in the 1961 Englewood Lumber Co. decision. ${ }^{38}$ There a union organizer had obtained signatures on authorization cards by telling the signers that the purpose of the cards was to obtain an election; he did not tell them that the cards also authorized his union to act as their exclusive bargaining representative. The Board held that the cards could not be used to establish a section $8(a)(5)$ violation: "[W]e do not think it can reasonably be said that the employees, by their act of signing authorizations, thereby clearly manifested an intention to designate the Union as their bargaining representative." 39

Although the Englewood decision appeared at the time to be based on the simple idea that misrepresentation as to a card's purpose will invalidate it, it was interpreted in quite a different way only two years later in Cumberland Shoe Corp.40 In Cumberland, as in Englewood, union organizers had solicited signatures by telling the signers that the purpose of signing was to obtain an election. The Board, however, distinguished Englewood and arrived at an entirely different result. In Englewood, the Board noted, the union organizer had told the signers that the only purpose of the cards was to obtain an election; in the instant case, on the other hand, "the cards, on their face, explicitly authorized the Union only to act as bargaining agent of the employees, and ... the failure of the Union's solicitors to affirmatively restate this authorization does not indicate that it was abandoned or ignored." 41 In view of this fact, there was no reason to believe that the union had beguiled employees into signing cards and consequently no reason to hold invalid the cards obtained.

Thus, according to Cumberland, the validity of authorization cards

37 Lebanon Steel Foundry v. NLRB, 130 F.2d 404, 407 (D.C. Cir. 1942).

38130 N.L.R.B. 394, 47 L.R.R.M. 1304 (1961); accord, NLRB v. Koehler, 328 F.2d 770 (7th Cir. 1964); Morris \& Associates, Inc., 138 N.L.R.B. 1160, 51 L.R.R.M. 1183 (1962). See NLRB v. Abrasive Salvage Co., 285 F.2d 552 (7th Cir. 1961).

39130 N.L.R.B. at 395,47 L.R.R.M. at 1305.

40 144 N.L.R.B. 1268, 54 L.R.R.M. 1233 (1963); accord, NLRB v. Gotham Shoe Mfg. Co., No. 29793, 2d Cir., Jan. 14, 1966; Happach v. NLRB, No. 15079, 7th Cir., Nov. 29, 1965; Aero Corp., 149 N.L.R.B. No. 114, 57 L.R.R.M. 1483 (Nov. 30, 1964).

41144 N.L.R.B. at 1269, 47 L.R.R.M. at 1233. 
depends on the union organizer's use or nonuse of the word "only." If an organizer states that the purpose of the cards he is handing out is to obtain an election, but carefully refrains from using the word "only," or if he merely talks about an election generally, the signatures he obtains will be deemed valid evidence of the signers' intent to authorize his union to act as their exclusive bargaining representative. Only if he states that the sole purpose of the cards is to obtain an election will the signatures be held invalid.

In practice, Cumberland has proved to be an umbrella under which many questionable forms of union solicitation can be accommodated. In one recent case, ${ }^{42}$ for example, the signer of a disputed card testified that he could not read and could write only his name, that no one had read the card to him, and that everything but his signature had been filled in by someone else. He also testified that the only things he could remember about signing were that the union solicitors had told him that they wanted the card signed so that there could be an election, and that everyone else was complying with this request. The card was held to be valid.

Cumberland has also had the effect of sanctioning the use of authorization cards the text of which is misleading. Such cards typically take the form of "dual purpose", cards, emphasizing a demand for an election but providing an authorization for collective bargaining in small type. For example, a card held to be valid in one recent case read:

Petition and Authorization to Show That

\section{WANT AN NLRB ELEGTION NOW}

I, the undersigned, an employee of hereby authorize the International Electrical Radio and Machine Workers, IUE-AFL-CIO, to petition the National Labor Relations Board for an election as soon as possible.

I authorize the IUE-AFL-CIO to act as my bargaining agent with the company in regard to wages, hours and working conditions. ${ }^{43}$

Under the Cumberland rule such cards presumably are valid as long

42 Gotham Shoe Mfg. Co., 149 N.L.R.B. No. 80, 57 L.R.R.M. 1385 (Nov. 19, 1964), $a f f^{\prime} d$, No. 29793, 2d Cir., Jan. 14, 1966.

43 S. N. C. Mfg. Co., 147 N.L.R.B. 809, 813, 56 L.R.R.M. 1313, 1314 (1964), enforced in part and rev'd in part sub nom. International Union of Elec. Workers v. NLRB, 350 F.2d 791 (D.C. Cir. 1965); see NLRB v. Peterson Bros. Co., 342 F.2d 221 (5th Cir. 1965); NLRB v. Winn-Dixie Stores, Inc., 341 F.2d.750 (6th Cir. 1965). The use of dual purpose cards was criticized in both Electrical Workers and Peterson Brothers, but in neither was such practice held to be unlawful. 
as they do not state that their sole purpose is that of obtaining an election. ${ }^{44}$

The Board's decision in Cumberland was enforced by the Sixth Circuit Court of Appeals. ${ }^{45}$ However, in a somewhat earlier case, NLRB v. Peterson Brothers, Inc., ${ }^{46}$ the Fifth Circuit refused to enforce a Board decision based on principles similar to those applied in Cumberland. The union's majority in Peterson hinged on the validity of three dual purpose cards. Two of these had been signed in response to a plea from a union organizer that "the only thing I am asking you to do is sign the card; regardless of how you vote-I would like for you to sign the card so that we could have the election." 47 The third had arrived by mail at the alleged signer's home while he was away at work, and his wife had signed it in his name and returned it. The husband had not tried to get the card back because his employer had told him that the cards did not make any difference since there was going to be a Board election. ${ }^{48}$

The Board determined that all three of the cards were valid; the Fifth Circuit held that none was. The court explained its decision as follows:

In view of the language on the face of the card that "this is not an application for membership" and the language that in the alternative it is "for an NLRB election" we think there was a burden on the General Counsel to establish by a preponderance of the evidence that the signer of the card did, in effect, what he would have done by voting for the union in a Board election. We think that in refusing to consider the subjective intent of the signer of the card, in the light of the ambiguity on the face of the card, the Board erred. ${ }^{49}$

Thus, the Peterson decision impliedly rejects the reasoning underlying Cumberland. To require that the General Counsel "establish by a preponderance of the evidence that the signer of the card did, in effect, what he would have done by voting for the union in a Board election" is to require a great deal more than a mere demonstration by the General Counsel that the signer was not told that the only purpose of the card was to obtain a Board election. In place of the narrow, me-

44 In Bannon Mills, Inc., 146 N.L.R.B. 611, 55 L.R.R.M. 1370 (1964), the Board held invalid cards reading "For Election Only."

45351 F.2d 917 (6th Cir. 1965).

46342 F.2d 221 (5th Cir. 1965), enforcing in part and reversing in part 144 N.L.R.B. 679, 54 L.R.R.M. 1113 (1963).

47 144 N.L.R.B. at 689 . See generally $i d$. at $689-91$.

$48 \mathrm{Id}$. at $694-96$.

49342 F.2d at 224 . 
chanical approach of the Cumberland rule, which hinges on the use or nonuse of a single word, the Peterson decision substitutes a broader, more subjective approach, which considers not only the circumstances in which the card was signed but also the signer's own comprehension of what he was doing.

The Cumberland rule seems difficult to justify. The Board has never offered a rationale for this lowering of standards; indeed, Cumberland itself seemed to be based on little more than a distinguishing of the Englewood precedent. Yet the effects of the Cumberland rule are drastic. An employee can be deemed to have signed a valid authorization card even though he had no intention of authorizing a union to act as his exclusive bargaining representative; an employer can be compelled to recognize and bargain with a union on the basis of evidence that does not indicate what it is said to indicate. Moreover, the laxness of the standards set out in Cumberland is inconsistent with the strict care taken to assure the existence of "laboratory conditions" for representation elections. It thus appears that the Cumberland rule operates unfairly against both employees and employers and cannot be regarded as sound doctrine.

To rehabilitate this area of refusal-to-recognize law the Board might institute two new policies. First, it might prohibit the use of dual purpose cards and prescribe separate standard forms for exclusive bargaining authorization and request-for-election cards. ${ }^{50}$ Since such a policy would in no way limit the number of circumstances in which the card check process could be employed, it would place only minimal burdens on union organizing efforts. Yet, the automatic rejection of cards that do not meet previously established standards would both obviate the necessity for time-consuming hearings and eliminate one of the most obvious areas of abuse in refusal-to-recognize law.

Second, the Board might hold that union misrepresentation of any sort will invalidate authorization cards for the purpose of establishing section $8(a)(5)$ violations. Institution of a rule of this nature would assure that signers of cards would not be actively misled as to the significance of their signing. Moreover, the difficulties that would be involved in the enforcement of such a rule would be no greater than those currently involved in the enforcement of the Cumberland rule and would be considerably less than those that would be involved in the enforcement of a rule which, like the one in Peterson, hinged upon an inquiry into the subjective intent of card signers. Although Peterson would appear to indicate otherwise, the Board and the courts have

50 Suggestions as to how this could be done are made in Lewis, supra note 12, at 441 . 
generally been reluctant to inquire into the states of mind of the signers of authorization cards. ${ }^{\text {b1 }}$ Such reluctance appears justified. Since hearings on refusal-to-recognize charges often take place months or even years after the card solicitations that provide the basis of the charges, ascertaining the thoughts of the signers of the cards at the time of their signings would pose very substantial fact finding burdens. Between the time of the card campaign and the time of the trial examiner's hearing employees might, for example, have forgotten their original motivation, changed their views on unionism, or moved to a different city. Moreover, it is doubtful whether such an inquiry, even if possible, would be worth the time and expense required. The Board does not inquire into the states of mind of employees voting in a Board election, and there appears to be no clear reason why a different rule should be applied to the signing of authorization cards, particularly since testing union authorization cards by an objective standard would appear to offer a relatively easy way to eliminate some of the shortcomings of the card check process.

\section{The Employer's Right To Insist Upon a BoArd Election:}

\section{The Fred Snow Decision}

The apparent availability of both the election and certification provisions of section 9 of the NLRA and the refusal-to-recognize provisions of section $8(a)(5)$ has been the source of much confusion in the development of the law of union recognition procedures. Section 9 states that whenever "a question of representation" exists, an employer has the right to insist that the union seeking recognition demonstrate its alleged majority support by participating in a Board election. ${ }^{52}$ Left unresolved by the statute is whether the employer's right to insist upon an election under section 9 applies despite a union's purported satisfaction of the section 8(a)(5) requirements for recognition.

The earliest cases on this issue made it clear that an employer presented with evidence of purported majority support did not have an automatic right to insist upon an election..$^{53}$ Not until the landmark case of Joy Silk Mills, Inc. v. NLRB ${ }^{54}$ in 1950, however, were the cir-

51 See note 36 supra and accompanying text.

5261 Stat. 143 (1947), 29 U.S.C. § 159 (1964).

53 See, e.g., NLRB v. Federbush Co., 121 F.2d 954 (2d Cir. 1941); NLRB v. Remington Rand, Inc., 94 F.2d 862 (2d Cir.), cert. denied, 304 U.S. 576 (1938); L. B. Hartz Stores, 71 N.L.R.B. 848, 19 L.R.R.M. 1056 (1946). But see North Elec. Mfg. Co. v. NLRB, 123 F.2d 887 (6th Cir. 1941), cert. denied, 315 U.S. 818 (1942); NLRB v. Empire Furniture Corp., 107 F.2d 92 (6th Cir. 1939).

54185 F.2d 732 (D.C. Cir. 1950), cert. denied, 341 U.S. 914 (1951). 
cumstances in which an employer had the right to insist upon an election clearly set forth. According to Joy Silk:

[A]n employer may refuse recognition to a union when motivated by a good faith doubt as to the union's majority status. ... When, however, such refusal is due to a desire to gain time and to take action to dissipate the union's majority, the refusal is no longer justifiable and constitutes a violation of the duty to bargain set forth in section $8(a)(5)$ of the Act.55

The Joy Silk doctrine gained immediate and widespread acceptance. ${ }^{56}$ Nevertheless, during eleven years of Board and judicial interpretation a question remained whether the phrase "good faith doubt as to the union's majority status" referred only to an employer's doubts that a union's card majority had been validly obtained without such illegality as forgery or threats, or whether "good faith" referred also to doubts that the acquisition of a valid card majority provides a generally reliable guide to actual employee sentiment. ${ }^{57}$

The Board finally resolved the question in the Fred Snow case of $1961 .{ }^{58}$ The employer admitted that the union had obtained valid au-

$55 I d$. at 741. It had been assumed until recently that the burden of proving that the employer's refusal to bargain was in bad faith was on the General Counsel. Glenn Koennecke, 113 N.L.R.B. 1172, 36 L.R.R.M. 1427 (1955). In a recent case, however, the Board appeared to place the burden of proving his good faith upon the employer. Mitchell Concrete Prods. Co., 137 N.L.R.B. 504, 50 L.R.R.M. 1192 (1962).

56 See, e.g., NLRB v. Nelson Mfg. Co., 326 F.2d 397, 399-400 (6th Cir. 1964); NLRB v. Decker, 296 F.2d 338, 341 (8th Cir. 1961); NLRB v. Stow Mfg. Corp., 217 F.2d 900, 904-05 (2d Cir. 1954), cert. denied, 348 U.S. 964 (1955); NLRB v. Trimfit, 211 F.2d 206, 209-10 (9th Cir. 1954); NLRB v. Stewart, 207 F.2d 8, 13 (5th Cir. 1953); NLRB v. Epstein, 203 F.2d 482, 484 (3d Cir. 1953); NLRB v. Jackson Press, Inc., 201 F.2d 541, 544-45 (7th Cir. 1953). Among the cases in which it was found that an employer had a good faith doubt as to the union's majority status are NLRB v. Johnnie's Poultry Co., 344 F.2d 617 (8th Cir. 1965) (question of how many employees were permanent members of the bargaining unit); NLRB v. Bedford-Nugent Corp., 317 F.2d 861 (7th Cir. 1963) (union failing to obtain cards from a majoxity of the employees until after it presented its demand for recognition); NLRB v. Porter County Farm Bureau Co-op. Ass'n, 314 F.2d 133 (7th Cir. 1963) (union that had previously represented employees in multi-employer bargaining arrangement seeking recognition as agent for single employer bargaining); NLRB v. Dan River Mills, 274 F.2d 381 (5th Cir. 1960) (question of the validity of certain cards in an extremely close count in a very large bargaining unit). Among the articles praising the Joy Silk doctrine while criticizing other of the Board's policies in the refusal-to-recognize area is Sandler, supra note 12 .

57 But see NLRB v. Hannaford Bros. Co., 261 F.2d 638 (1st Cir. 1958). The court in that case refused to enforce a $\$ 8(a)(5)$ bargaining order based on a validly obtained union card majority. One of the reasons for the court's decision was that since reports had reached the employer that a number of the signers of the cards were dissatisfied with the union, desired to defect from it, and intended to vote against it in a forthcoming election, the employer "had every reason to doubt that the Union was the uncoerced choice of a majority of the employees in the . . plant." Id. at 641 .

58134 N.L.R.B. 709, 49 L.R.R.M. 1228 (1961), enforced, 308 F.2d 687 (9th Cir. 1962). 
thorization cards from a majority of his employees. He defended his refusal to bargain without an election on the grounds that he had sincerely doubted that the union's card majority accurately reflected the true sentiments of his employees and that he had not desired to take advantage of the delay caused by holding an election to dissipate the union's alleged majority. Although the Board did not doubt his testimony, it refused to accept his theory of law. Refusal to recognize in the absence of a good faith doubt as to the validity of a union's card majority, it ruled, itself constitutes a violation of section $8(a)(5)$. On appeal, the Ninth Circuit agreed.

The Snow rule has been followed in several subsequent Board decisions. ${ }^{59}$ However, it has been condemned by commentators ${ }^{60}$ and would be overturned by the passage of either of two bills currently pending before the Senate. ${ }^{61}$ Possibly in reaction to this controversy, the Board, in the recent case of John P. Serpa, Inc. ${ }^{62}$ went to lengths to distinguish Snow. The facts of Serpa were virtually identical to those of Snow, except that in the former the employer himself had examined the authorization cards, whereas in Snow that task had been delegated to a neutral third party. Seizing upon this slight factual difference, the Board ruled that Snow was "clearly distinguishable" and refused to issue a bargaining order. "The fact that the Union placed the cards in front of the Respondent," it reasoned, "cannot create the obligation to bargain or establish Respondent's bad faith."63

The Serpa holding thus places the status of the Snow rule in considerable doubt. It is clear that an employer has the right to insist upon an election when his refusal to recognize is motivated by a good faith doubt that the union's card majority was validly obtained, and does not have such a right when his refusal to recognize is due to a desire to gain time and to take action to dissipate the union's majority. Under existing law it is, however, unclear whether the employer has a right to

69 See, e.g., Dixon Ford Shoe Co., 150 N.L.R.B. No. 4I, 58 L.R.R.M. 1160 (Oct. 29, 1965); Fleming \& Sons, Inc., 147 N.L.R.B. 1271, 56 L.R.R.M. 1393 (1964); Kellogg's, Inc., 147 N.L.R.B. 342, 56 L.R.R.M. 1223 (1964), enforced, 347 F.2d 219 (9th Cir. 1965); Air Filter Sales \& Serv., Inc., I42 N.L.R.B. 384, 53 L.R.R.M. 1052 (1963); George Groh \&: Sons, 141 N.L.R.B. 931, 52 L.R.R.M. 1424 (1963), enforced, 329 F.2d 265 (10th Cir. 1964).

co See, e.g., Shuman, Requiring a Union To Demonstrate Its Majority Status by Means of an Election Becomes Riskier, 16 LAB. L.J. 426, 429 (1965); Sandler, supra note 12.

61 S. 2133, 89th Cong., 1st Sess. (1965) (introduced by Senator Javits); S. 2226, 89th Cong., 1st Sess. (1965) (introduced by Senator Fannin). Both bills would amend the NLRA to provide that an employer need not recognize and bargain with a union that has not been certified in accordance with the provisions of $\$ 9$ unless he has used unfair labor practices to try to destroy the union's majority.

62155 N.L.R.B. No. 12, 60 L.R.R.M. 1235 (May 5, 1965).

63 Id., 60 L.R.R.M. at 1235. 
insist upon an election when his refusal to recognize stems from a doubt that a valid card majority accurately reflected his employees' true sentiments.

The confusion surrounding the narrow Snow rule and the comparative certainty of the Board's rules governing other problems in this area reflect the policies underlying the various situations. Where grounds exist for a bona fide doubt as to the validity of a union's card majority and where at the same time there is no obstacle to the holding of a fair election, there would appear to be no reason to bar an employer from insisting upon the latter procedure. Indeed, in such a situation the holding of an election offers the only trustworthy way of determining the true sentiments of the employees concerned. ${ }^{64} \mathrm{Com}$ pelling reasons also urge that an employer should be denied the right to insist upon an election when his refusal to recognize is due to a desire to gain time and to take action to dissipate the union's support. ${ }^{65}$ In a situation in which an employer intends to embark on a campaign to destroy union support, the prompt holding of an election that will meet the "laboratory conditions" standard of the NLRB is probably not possible; consequently, reliance on card check results seems justified despite that procedure's admitted shortcomings. This reasoning would appear to apply regardless of whether the employer also has a good faith doubt as to the validity of the union's card majority. Such a doubt would not make the holding of a fair election any more possible, and if he could persuade the Board that the card majority was in fact invalid, the employer would not be prejudiced because the Board would not issue a bargaining order.

It is the situation dealt with in Snow, then, that raises the really difficult problems in this area. When an employer seeks an election even though he has neither a good faith doubt as to the validity of the union's card majority nor a desire to gain time and to take action to dissipate the union's support, he is indicating a disbelief in the reliability of the card check process. Whether the law should tolerate such a position can be determined only with reference to the question

64 It should be remembered that in International Ladies' Garment Workers v. NLRB, 366 U.S. 731, 738 (1961), the Supreme Court said that it is just as much an unfair labor practice for an employer to extend recognition to a minority union as it is for him to refuse to recognize a majority union.

65 It must be presumed that the term "action" destructive of union support refers only to independent acts of illegality, not to acts sanctioned by the "free speech" provisions of \$ 8(c) of the NLRA. Otherwise, the Board would be placed in the anomalous position of denying elections requested by employers on the grounds that the employers desired to engage in action specifically authorized by the statute. 
whether card checks are in fact unreliable indicators of employee sentiment.

The evidence on this point supports the belief that card checks are not as reliable a method of determining union support as are Board elections. ${ }^{66}$ Nevertheless, it may be worthwhile to inquire whether any considerations make the use of card checks preferable to elections even granting the former procedure's serious shortcomings. At one time it might plausibly have been argued that card checks were a faster and more economical method of ascertaining union strength than were elections. However, under the Board's new procedures, which permit regional directors to order and supervise elections without first referring to Washington, unions are able to obtain elections within ten to seventy days from the filing of a petition, and the Board is able to conduct large numbers of elections with a minimum of administrative inconvenience. ${ }^{67}$ Consequently, it would appear that considerations of speed and economy no longer offer a compelling argument for the use of the card check process.

In view of the greater reliability afforded by use of election procedures and the absence of major factors favoring use of card check determinations, there would appear to be little justification for a rule requiring, as Snow does, exclusive reliance on card check results in situations in which the prompt holding of a Board election is possible. Therefore, it would appear that the wisest course the Board could follow would be to abandon completely the Snow rule and hold that in the absence of a desire to gain time and to take action to dissipate the union's majority an employer will retain his right to insist upon an election.

\section{The Union's Right To Bring a Refusal-To- Recognize Charge After a Board Election: THE Bernel Foam DECISION}

The relative significance to be accorded card checks and elections is squarely at issue when a refusal-to-recognize charge is brought by a union which subsequent to obtaining a valid card majority has lost a Board election. The Board has changed position twice in the past fifteen years as to whether unions can bring refusal-to-recognize charges under such circumstances. Having held in the early 1950's that loss of an election was not a bar to the bringing of refusal-to-recognize charges, ${ }^{68}$ the

66 See text accompanying notes $22-31$ supra.

67 Shuman, supra note 60 , at 428 .

68 E.g., Southeastern Rubber Mfg. Co., 106 N.L.R.B. 989, 32 L.R.R.M. 1590 (1953), enforced, 213 F.2d 11 (5th Cir. 1954); Model Mill Co., 103 N.L.R.B. 1527, 32 L.R.R.M. 
Board reversed itself in 1954 in Louis Aiello. ${ }^{69}$ Bernel Foam Products $C o .{ }^{70}$ reinstitutes the policy of the early 1950 's.

Extensive analytical discussions in both the Aiello and Bernel Foam opinions illuminate some of the principal problems in this area. The. Aiello Board perceived two objections to the bringing of refusal-torecognize charges after a Board election. First, refusal-to-recognize charges and election proceedings were based on "fundamentally different premises": ${ }^{71}$ whereas election proceedings assume that a question of representation exists, refusal-to-recognize charges assume that no question of representation exists and that the union seeking recognition is in fact the lawful bargaining representative of the employees concerned. Consequently, the two remedies could not both be appropriate in the same set of circumstances. ${ }^{72}$ Second, permitting the bringing of refusal-to-recognize charges after Board elections would be contrary to sound administrative practice. A union, by delaying its refusal-to-recognize charge until after it has participated in an election, circumvents the Board's sound practice of not conducting elections during the pendency of refusal-to-recognize charges. To avoid "useless and repetitive proceedings," unions should be limited to a single choice of remedies. Consequently, there is no justification "for permitting a labor organization after it has thus resorted to a representation election with knowledge of unfair labor practices to revert to a Section $8(a)(5)$ proceeding based on the same unfair labor practices as a means of establishing its representative status." 73

The Bernel Foam Board, by examining the circumstances in which refusal-to-recognize charges are used, brought out points that appear to meet the Aiello Board's two objections. First, in actual practice

1001 (1953), enforced, 210 F.2d 829 (6th Cir. 1954); Stow Mfg. Co., 103 N.L.R.B. 1280, 31 L.R.R.M. 1635 (1953), enforced, 217 F.2d 900 (2d Cir. 1954), cert. denied, 348 U.S. 964 (1955); Howell Chevrolet Co., 95 N.L.R.B. 410, 28 L.R.R.M. 1340 (1951), enforced, 204 F.2d 79 (9th Cir.), aff'd, 346 U.S. 482 (1953); Joy Silk Mills, Inc., 85 N.L.R.B. 1263, 24 L.R.R.M. 1548 (1949), enforced, 185 F.2d 732 (D.C. Cir. 1950), cert. denied, 341 U.S. 914 (1951).

69 ' 110 N.L.R.B. 1365, 35 L.R.R.M. 1235 (1954).

70146 N.L.R.B. 1277, 56 L.R.R.M. 1039 (1964), Comment, Union Permitted To File Refusal-To-Bargain Charge After Losing Representation Election, 39 N.Y.U.L. REv. 866 (1964); Note, Labor Law-Refusal-To-Bargain Charges After Representation Election, 19 Sw. L.J. 378 (1965); Comment, NLRB Reverses "Election of Remedies" Doctrine To Permit Refusal To Bargain After Representation Election, 113 U. PA. L. REv. 456 (1965); accord, International Union of Elec. Workers v. NLRB, 350 F.2d 791 (D.C. Cir. 1965); Irving Air Chute v. NLRB, 350 F.2d 176 (2d Cir. 1965); Colson Corp. v. NLRB, 347 F.2d 128 (8th Cir.), cert. denied, 34 U.S.L. WEEK 3160 (U.S. Nov. 9, 1965) (No. 468); Edro Corp. v. NLRB, 345 F.2d 264 (2d Cir. 1965).

71 Louis Aiello, 110 N.L.R.B. 1365, 1368, 35 L.R.R.M. 1235, 1236 (1954).

72 Ibid.

73 Ibid. 
refusal-to-recognize charges and election proceedings are not based on the contradictory assumptions that the union both is and is not the employees' representative. Although a union, by seeking an election after it has submitted card check evidence of majority support, asserts as a formal matter that a question of representation exists, as a practical matter it does not alter its position that it represents the employees and is entitled to recognition; rather, by requesting an election it is seeking to prove that it does represent the employees. Moreover, the election and section $8(a)(5)$ proceedings determine different issues of fact; an election determines the union's support on the date of the election, while the section $8(a)(5)$ refusal-to-recognize charge determines support on the date of the employer's refusal to bargain. ${ }^{74}$ Second, considerations of sound administrative practice may actually favor permitting the bringing of refusal-to-recognize charges after Board elections. The Aiello approach discourages unions from proceeding to elections when they have a chance to obtain recognition by bringing refusal-to-recognize charges based on previously obtained card check majorities. But if unions knew they could bring refusal-tobargain charges despite having participated in elections, they would be more willing to proceed to elections; and, because they would win some of those elections, they would bring fewer refusal-to-recognize charges. ${ }^{75}$

An important problem that emerges in the wake of Bernel Foam is the relationship between the bringing of refusal-to-recognize charges after an election, and Snow's provision that an employer can be held to have violated section $8(a)(5)$ even though he has shown no desire - to gain time to take action to dissipate the union's majority. Much of the Bernel Foam Board's reasoning appeared to be based on the assumption that postelection refusal-to-recognize charges would be brought only if the union could demonstrate that the employer had interfered with the conduct of the election. Nevertheless, application of the Snow rule to postelection refusal-to-recognize charges was not specifically prohibited. Thus, Bernel Foam leaves open the possibility that an employer could be compelled to recognize and bargain with a union even though he had made no attempt to dissipate the union's alleged majority and even though the union had in the interim lost a Board election.

The Board dealt with this problem in the recent case of Kolpin Bros. $\mathrm{Co}^{76}$ by ruling that refusal-to-recognize charges filed after the union

74 Bernel Foam Prods. Co., 146 N.L.R.B. 1277, 1279-80, 56 L.R.R.M. 1039, 1040-41 (1964). $75 \mathrm{Id}$. at 1281-82, 56 L.R.R.M. at 1041 .

76149 N.L.R.B. No. 127, 57 L.R.R.M. 1457 (Dec. 7, 1964); accord, Irving Air Chute Co., 
seeking recognition has lost an election will not be acted upon unless the election in question has been set aside on the basis of meritorious objections filed in the representation proceeding. Unfortunately, however, Kolpin Bros. does not entirely solve the problem. Meritorious objections to an election may relate to acts of misconduct by the employer, by third parties such as a local Chamber of Commerce or newspaper, or to administrative errors by the Board. Insofar as the meri. torious objections spoken of in Kolpin Bros. may include either of the latter two types, charges lacking evidence of employer misconduct will still be considered and the problem of the application of the Snow and Bernel Foam rules in tandem will not have been eliminated.

Permitting a union to bring refusal-to-recognize charges after a Board election appears justifiable where there is evidence that the employer interfered with the conduct of the election. Employer interference with the conduct of a Board election eliminates for a considerable period of time the possibility of holding a "laboratory conditions" election in the same unit, ${ }^{77}$ leaving reliance on card check results as the most satisfactory method for determining employees' sentiments. Thus, to prohibit reliance on card check results here would permit employers to take advantage of their unfair labor practices. ${ }^{78}$

- However, there would appear to be little justification for permitting the bringing of refusal-to-recognize charges where it cannot be shown that the employer interfered with the conduct of the election. Generally in such a situation there will be no reason to suspect that the election result does not accurately reflect the sentiments of the employees concerned and hence no reason not to regard the union's evidence of a card majority as evidence already disproved. If, on the other hand, the election result has been set aside because of acts of misconduct by third parties or administrative errors by the Board, the prompt holding of a new Board election will usually offer the most satisfactory method of determining the employees' true sentiments. Therefore, the Board should clarify its policies to provide that refusalto-recognize charges filed after a Board election will be acted upon only if it can be shown that the employer interfered with the conduct of the election in question. This could, of course, effectively be accomplished by a clear abandonment of the Snow rule.

149 N.L.R.B. No. 59, 57 L.R.R.M. 1330 (Nov. 12, 1964) (dictum), enforced, 350 F.2d 791 (2d Cir. 1965).

77 Bernel Foam Prods. Co., 146 N.L.R.B. 1277, 1281, 56 L.R.R.M. 1039, 1041 (1964).

78 "We would thus be punishing the wronged party for the misdeeds of the wrongdoer, were we to prevent the union from instituting $8(a)(5)$ proceedings in order to remedy the respondent's unfair labor practices." Id. at 1281-82, 56 L.R.R.M. at 1041. 


\section{Conclusion}

The Board should adopt stricter rules as to the use of refusal-torecognize charges in settling issues of union recognition than those now employed. The Cumberland rule, which provides that the only type of statement by a union organizer that will invalidate an authorization card is one that the sole purpose of the card is to obtain a Board election, and the Snow rule, which provides that an employer violates section $8(a)(5)$ if he refuses to recognize a union because he doubts the reliability of the union's card majority, should both be abandoned. No effect should be given to authorization cards obtained by union misrepresentation or to ambiguous "dual purpose" cards, and even validly obtained card majorities should be relied upon only when the prompt holding of a fair NLRB election is impossible.

Abandonment of the Board's current policies would, of course, adversely affect union organizing efforts in two important respects. First, unions would find it more difficult to obtain valid card majorities, and second, they would at times be forced to participate in NLRB elections where they would otherwise have obtained recognition on the basis of refusal-to-recognize charges. But if a primary purpose of the recognition procedures of the NLRA is the protection of employee free choice, such results cannot be regarded as undesirable. 